\title{
CORRESPONDENCE
}

Correspondents are asked to be brief

\section{Is Salmon a Scapegoat?}

J. W. Paulley, F.R.C.P....... . . . . . .716

Peripatetic Psychopenal Disorder

E. W. Shepherd, F.R.C.PSYCH. . . . . . .716

Communications between General Practitioners and Consultants

N. V. Birrell, M.R.C.P.; J. M. Bevan, M.A., and

K. S. Dawes, M.R.c.G.P.; Margaret

B. Noble, M.R.c.o.G..............717

Accidental Hypothermia: Central Rewarming in the Field

E. LL. Lloyd, F.F.A.R.C.S., and J. C.

Frankland, M.B., M.R.c.G.P.........717

Safety and Fibreoptic Bronchoscopy

P. Stradling, F.R.C.P., and G. W. Poole,

M.R.C.P.; D. J. Hendrick, M.R.C.P., and

J. Cowie, M.R.C.P..............717

Full View of the Road

R. A. Weale, D.sc.............. 718
Uticillin

D. S. Reeves, M.R.C.PATH. . . . . . . . . 718

Skin Reactions to Beta-blockers

Constance M. Ridley, F.R.C.P.........7719

Medical Nemesis

C. R. Porteous, M.R.c.o.g. . . . . . . . .719

Acute Calf Swelling

B. Thalayasingham, M.R.C.P., and others. . . 719

Lorazepam Poisoning

D. I. Jeffrey, M.B., and M. F. Whitfield,

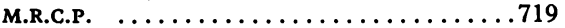

The Roseolar Reaction

G. I. Watson, F.R.C.G.P...........719

Hernias in Children

E. O. Goodrich, jun., M.D. . . . . . . . . . 720

In Arduis Fidelis

Colonel D. Hamilton, M.R.C.P. . . . . . . . 720

Medicine and the Common Market

K. Liddell, M.R.C.P............. 720
Ethyloestrenol

C. J. Mugglestone, M.B. ............7720

Agoraphobia

N. S. Capstick, M.D.; D. Waxman, M.R.C.S. . 720

Consultant Contract

R. S. Francis, F.R.C.P., and others; E. B.

Lewis, F.F.A.R.C.S.; P. A. D. Williams,

F.F.A.R.C.S. $\ldots \ldots \ldots \ldots \ldots \ldots \ldots \ldots \ldots 721$

Needs of Junior Hospital Doctors

D. E. F. Newton, M.B.............721

Other Health Services



Weakness in Negotiation

M. J. Clay, M.B...............722

Confinement Fee

N. E. Rust, M.B.; D. J. Leeming, M.B. . . . . 722

Knocking the B.M.A.

C. D. Campbell, M.B............722

\section{Is Salmon a Scapegoat?}

SIR,-At the meeting to discuss "A new role for the clinical nurse" and "The specialist nurse" at the Royal College of Physicians on 28 November, as reported in your leading article ( 7 December, p. 550), a strong case was made for providing career opportunities, status, and pay, not less than those at present offered to nurse administrators, for those perverse enough to wish to remain real nurses rather than abandon their hard-won skills for administration. Competent administration is very important, but some of us feel that the new cult of consultation and decision-making within interlocked committees, eternally reporting upwards, downwards, and sideways, has lost its sense of propontion.

I suggested in the discussion that the concept of the specialist nurse was not really new. For at least half a century sisters who spent more than five years on a wand or unit dealing with any specialty such as medicine, surgery, orthopaedics, geriatrics, paediatrios, neurology, psychiatry, the operating theatre, or casualty, etc., have automatically become specialists and acquired special skills, many of which were not applicable to other specialties. I added that if career opportunity was to be offered to the specialist nurse a hierarchical structure, as in Salmon, should be avoided at all costs.

The case for recognition of special skills was cogently put by two nurses, Miss Law and Miss Baldwin, from what may be regarded as the newer specialties of a liver and a renal unit, while the older specialties were represented by a nurse from a midwifery unit, Miss Ashton. These nurses, all in the Salmon 7 grade, said they had found it generally unsuitable for their tasks because of its preponderant administrative component. It seemed that they were clearly asking for new grades with a predominant clinical component comparable to, but not synonymous with, Salmon 7 and 8 (and I would add 9).

Not surprisingly nurse administrators, who seemed to be in a majority at the meeting, seemed somewhat subdued at this point. I think it is now time to put a direct question to them as they alone have the power of recommendation, if not of yea or nay. Are they, the nurse administrators, now prepared to accept senior sisters or specialist nurse on ward or unit being granted the status and pay equivalent of Salmon 7 or 8 on merit and/or length of service without being compelled to move from that ward or unit where they had acquired their skills and where those skills can be most usefully deployed? If this were done a number of nursing officers, none too happy in their present role, would bring back their invaluable skills to the bedside, now desperately depleted of trained staff, by remustering into the new clinical grade. The cry will be that they cannot be spared from administration but I remain convinced that the latter is at present top-heavy and that much of the dayto-day work could be done by high-quality secretaries at the direction of nurse administrators.-I am, etc.,

Ipswich

\section{J. W. Paulley}

\section{Peripatetic Psychopenal Disorder}

SIR,-As Dr. Henry Rollin has pointed out, the "open door" of the modern psychiatric hospital may become a "revolving door" for a group of mentally abnormal or inadequate offenders who drift between destitution, prison, and psychiatric hospital.

Unaware of the benefits of the "open door" regime (except for easier departure from the grounds) and socially inadequate because of chronic schizophrenia, limited to subnormal intelligence, or abnormal personality, these citizens, mainly males, break the law and are sent, almost hapazardly, to prison or hospital by the courts. Unresponsive to outpatient therapy (psychiatrists are only human and cannot treat by telepathy), beyond the limited resources of social service departments, unacceptable at or aimlessly leaving those few residential alternatives to the psychiatric hospital, and lacking a conventional home, they repeatedly appear in court. Dr. Rollin has drawn our attention to this group of peripatetic patients and their unmet needs in his book ${ }^{1}$ and many articles and has earned respect for his spirited but perhaps premature exposure of this "unacceptable face" of the open psychiatric hospital.

A Lord Chief Justice recommended the greater use of restriction ordens to prevent the premature discharge by psychiatrists of dangerous offenders. I believe that care is indivisible from treatment and that to offer the latter we have to accept responsibility for ensuring the former-if necessary by locking a door or two. Unhappily there has been a failure to accept the need for action or even consideration of this problem and I write in the hope that by recognizing the existence of this gnoup of under-treated people we may avoid the alternatives"hospital prisons" or restriction orders. Neither of these procedures is really necessary, humane, or desirable, but until the community, magistrates, and above all psychiatrists deal more effectively with the situation, so long will this group of drifting patients periodically appear in court.-I am, etc.

\section{Leavesden Hospital,} Abbots Langley,

1 Rollin, H. R., The Mentally Abnormal Offender and the Law. Oxford, Pergamon, 1969. 